Review article

\title{
Depression and anxiety associated with COVID- 19 pandemic among healthcare professionals in India- A systematic review and meta-analysis
}

\author{
E.K. Abdulla, Saleena Ummer Velladath, Aneena Varghese, M. Anju \\ Department of Medical Laboratory Technology, Manipal College of Health Professions, Manipal Academy of Higher Education, Manipal, Karnataka, India
}

\section{A R T I C L E I N F O}

\section{Keywords:}

COVID-19

Mental health

Anxiety

Stress

Depression

India

\begin{abstract}
A B S T R A C T
Background: As India is fighting against the second wave of COVID-19, Healthcare professionals are the front-line warriors on that battlefield which puts them under psychological pressure, this systematic review aims to critically look into and amalgamate the evidence on impact of COVID-19 on psychological health of healthcare professionals in India and to seek the attention of policymakers.

Methods: A systematic literature search was performed using the following databases PubMed, SCOPUS, Web of Science, Cochrane Library, ScienceDirect. Additionally, random search in Google, Google Scholar and ResearchGate was also performed until February 2021. The methodological quality of studies was assessed using Downs and Black for reporting quality. Meta-analysis was performed using revMAN. The review protocol is registered in PROSPERO and is available online.

Result: Prevalence of depression was found to be present in $41.90 \%$ of 5796 participants in five studies (95\% Confidence Interval [CI]: 29.17 to 54.64), and prevalence of anxiety was found to be $42.87 \%$ common in 10 studies with a total sample size of 3059 people (95\% Confidence Interval [CI]: 30.26 to 55.49), Stress was found to be prevalent (58.04\%) in 12 studies with 4209 participants, (95\% CI: 44.81-71.28), Prevalence of sleeping problem in 3 studies with 416 participants recorded a prevalence rate of 31.94 (95\% CI: 21.38-42.49)

Conclusion: The COVID-19 pandemic has had a significant impact on people's mental and physical health, particularly among health-care workers. Authorities should develop programmes to help health-care workers improve their mental health.
\end{abstract}

\section{Introduction}

In December 2019, in a city of China called Wuhan has reported an outbreak of pneumonia caused by severe acute respiratory syndromecoronavirus-2 (SARS-CoV-2). The clinical characteristics of the disease is unpredictable as it varies from person to person. It differs from asymptomatic to mild symptom and to severe case like pneumonia., ${ }^{1,2}$ On March 11, 2020 WHO (World Health Organisation) issued a statement that COVID-19 as a global pandemic because of the exponential spreading of COVID-19 disease and increased death rate. ${ }^{3}$ COVID-19 (Coronavirus disease) was declared as PHEIC (Public Health Emergency of International Concern) for those countries who have poor health infrastructure, as alert for emerging infectious disease. ${ }^{4}$ On 30 January 2020 India reported first case of COVID-19 in the state Kerala. Since then till now our health care workers struggle to provide better treatment and care. ${ }^{5,6}$
In the battle against COVID-19 health care workers are the first line workers, as they are involved in the treatment and all other patient related work which put them under pressure. Long duty hours without sufficient rest, heavy work load, shortage of Personal Protective Equipment's and the high spread of infection accounts for severe stress anxiety and psychological distress creating a negative impact on mental health of health care workers. ${ }^{7}$ The health care population was concerned about the contagious infection, as there was high chance of them to get infected since they are more exposed to the traumatic or stressful situation, which created an adverse effect on their mental health outcome. $^{8}, 9$ According to WHO, 21,89,46836 confirmed cases and 45, 39,723 confirmed deaths of COVID-19 were reported across the globe on $3^{\text {rd }}$ September $2021 .{ }^{10}$ In India, so far $32,90,3289$ confirmed cases of COVID-19 were reported, with 43,98,95 confirmed deaths. ${ }^{11}$ Isolation, contact restrictions, and economic shutdown have all had a significant impact on the mental environment in the countries affected. Despite the

\footnotetext{
* Corresponding author. Dept. of Medical Laboratory Technology, Manipal College of Health Professions, Manipal Academy of Higher Education, Manipal, Karnataka, India.

E-mail address: anju.muraleedharan@manipal.edu (M. Anju).
} 


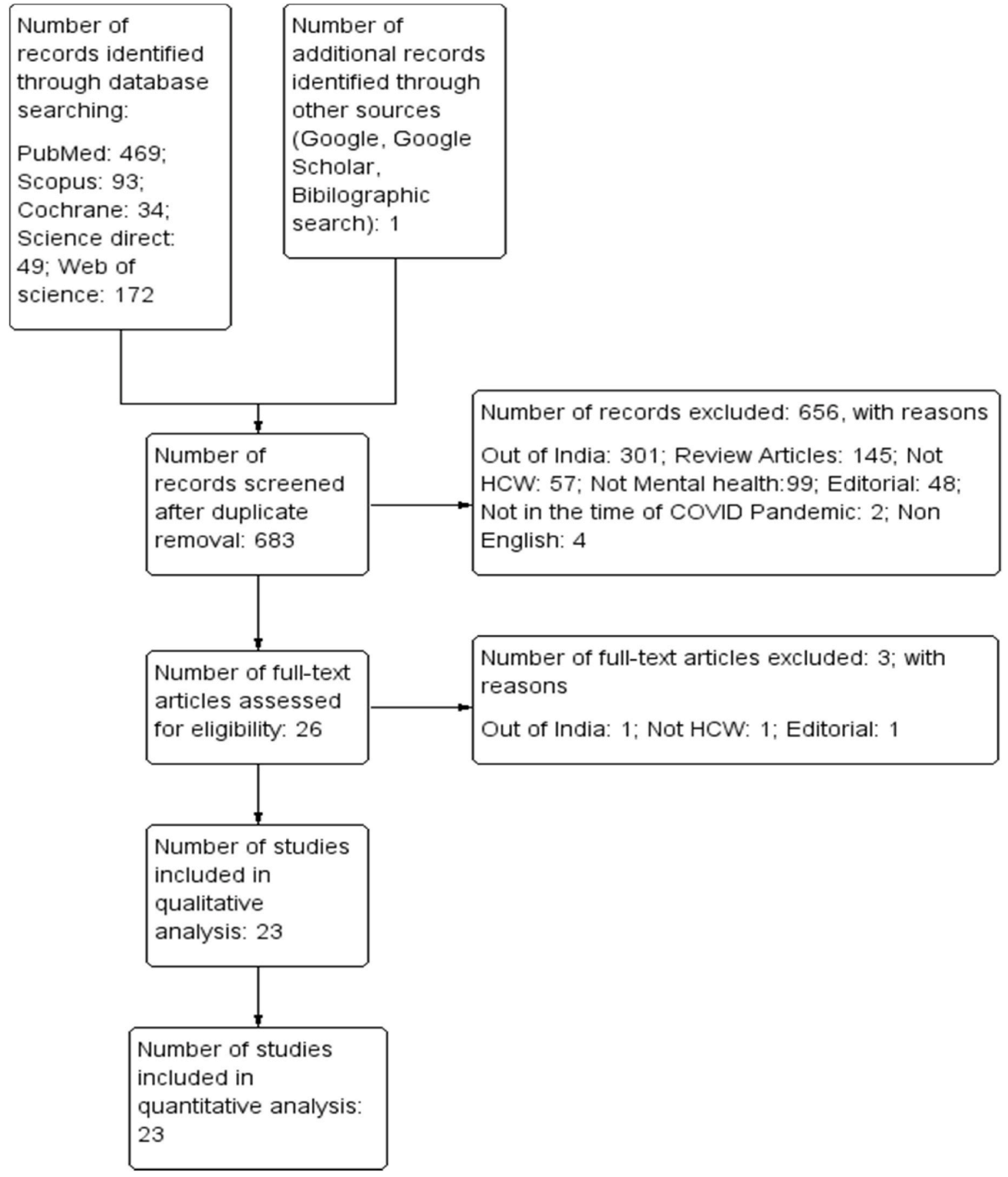

Fig. 1. The PRISMA Flow diagram for study selection.

fact that the current crisis may provide opportunity for personal growth and family bonding, many negatives outweigh these advantages. Anxiety, a lack of peer contact, and fewer opportunity to manage stress are all major problems. Aside from concerns and misgivings over COVID-19, the global economic situation has deteriorated, with high and rising unemployment rates. The current situation has a particularly negative impact on children, adolescents, and their families. Kindergartens and schools have been shuttered, social interactions have been severely restricted, and out-of-home leisure activities have been cancelled. Parents are encouraged to assist their children with home-schooling while working from home. ${ }^{12,13}$

The increasing number of cases, overload of work, depleting personal care equipment's and all other stressful situations together contributed to the burden of health care workers. They are worried about their family and friends, because of the high chance of them giving infection to their loved ones. All these thoughts add a huge impact on their mental health leading to a situation of stress, anxiety and depression symptoms. This could lead to long term impact on their psychological health. ${ }^{14}$ India is the second largest populated country in the world and, so it is critical to have access the mental health of Indian health care workers. Even though there are some studies already done on the topic but there is no review on this topic, for overall conclusion. Hence, we decided to conduct this systematic review on depression and anxiety associated with COVID- 19 pandemic among healthcare professionals in India. 
Table 1

Characteristics of the included studies.

\begin{tabular}{|c|c|c|c|c|c|c|c|c|}
\hline Author \& Year & Study Design & $\begin{array}{l}\text { Type of Questionnaire } \\
\text { used/Measures }\end{array}$ & $\begin{array}{l}\text { Type of } \\
\text { Participants (\%) }\end{array}$ & City/state of study & $\begin{array}{l}\text { Depression } \\
\%\end{array}$ & $\begin{array}{l}\text { Anxiety } \\
\%\end{array}$ & $\begin{array}{l}\text { Stress } \\
\%\end{array}$ & Result/conclusion \\
\hline $\begin{array}{l}\text { Rehman U et al., } \\
2021^{17}\end{array}$ & $\begin{array}{l}\text { Online survey } \\
\mathrm{n}=403\end{array}$ & $\begin{array}{l}\text { Family Affluence } \\
\text { Scale } \\
\text { Response Accuracy } \\
\text { Scale } \\
\text { Depression Anxiety } \\
\text { Stress Scale }\end{array}$ & $\begin{array}{l}\text { Students }(34.4 \%) \\
\text { Teachers }(12.6 \%) \\
\text { Researchers }(7.6 \%) \\
\text { Mental health } \\
\text { professionals } \\
(8.4 \%) \\
\text { Health } \\
\text { professionals } \\
\text { (Doctors and } \\
\text { Nurses) }(8.1 \%) \\
\text { Corporate job } \\
\text { workers }(8.6 \%)\end{array}$ & Not mentioned & NA & NA & NA & $\begin{array}{l}\text { Among various } \\
\text { professional's health } \\
\text { care professionals } \\
\text { were found to have } \\
\text { more depression, } \\
\text { anxiety and stress. }\end{array}$ \\
\hline $\begin{array}{l}\text { George C.E et al., } \\
2020^{18}\end{array}$ & $\begin{array}{l}\text { Mixed methods } \\
\text { survey } \mathrm{n}=87\end{array}$ & $\begin{array}{l}\text { Mixed methods } \\
\text { research with a } \\
\text { quantitative (QUAN) } \\
\text { design } \\
\text { Paradigm nested in } \\
\text { the primary } \\
\text { qualitative (QUAL) } \\
\text { design }\end{array}$ & $\begin{array}{l}\text { Doctors }(31.3 \%) \\
\text { Nurses }(21.9 \%) \\
\text { Allied health } \\
\text { Professionals } \\
(15.6 \%) \\
\text { Field staff }(21.9 \%) \\
\text { Others }(9.3 \%)\end{array}$ & Bangalore & NA & $73.4 \%$ & $62.5 \%$ & $\begin{array}{l}\text { Fear of getting } \\
\text { infection to their } \\
\text { family, fear of death, } \\
\text { and exhaustion were } \\
\text { the main reason for } \\
\text { stress among HCW }\end{array}$ \\
\hline $\begin{array}{l}\text { Shetty A et al., } \\
2020^{19}\end{array}$ & $\begin{array}{l}\text { Questionnaire- } \\
\text { based online } \\
\text { survey } n=405\end{array}$ & $\begin{array}{l}\text { Validated } \\
\text { questionnaire } \\
\text { (seventeen questions } \\
\text { divided into two } \\
\text { sections first } \\
\text { regarding the } \\
\text { demographic data of } \\
\text { the dentists and the } \\
\text { second comprised of } \\
\text { questions that aimed } \\
\text { to assess anxiety } \\
\text { levels and attitudes } \\
\text { toward CoviD-19 and } \\
\text { the subsequent } \\
\text { infection control } \\
\text { practices in } \\
\text { dentistry.) }\end{array}$ & Dentists & Not mentioned & NA & NA & NA & $\begin{array}{l}\text { Age of the dental } \\
\text { clinicians was found } \\
\text { to be a positive factor } \\
\text { and directly } \\
\text { proportional to a high } \\
\text { anxiety score. } \\
\text { The response scores } \\
\text { of anxieties in this } \\
\text { study indicate greater } \\
\text { psychological } \\
\text { pressure on the } \\
\text { dentists due to } \\
\text { uncertainty of } \\
\text { progression of the } \\
\text { pandemic }\end{array}$ \\
\hline $\begin{array}{l}\text { Suryavanshi N } \\
\text { et al., } 2020^{20}\end{array}$ & $\begin{array}{l}\text { Structured } \\
\text { online survey n } \\
=197\end{array}$ & $\begin{array}{l}\text { Patient Health } \\
\text { Questionnaire (PHQ- } \\
\text { 9) } \\
\text { Generalized Anxiety } \\
\text { Disorder (GAD-7) } \\
\text { questionnaire ne-item } \\
\text { quality of life (QoL-1) } \\
\text { visual analogue scale } \\
\text { multiple-choice } \\
\text { question by Shwu- } \\
\text { Hua Lee in Taiwan } \\
\text { during the SARS } \\
\text { outbreak }\end{array}$ & $\begin{array}{l}\text { Para clinical }(13 \%) \\
\text { Resident/intern } \\
(29 \%) \\
\text { Nurse }(24 \%) \\
\text { Physician }(34 \%)\end{array}$ & Maharashtra & $22 \%$ & $29 \%$ & NA & $\begin{array}{l}\text { Most of the HCW } \\
\text { reported of having } \\
\text { high anxiety, } \\
\text { depression, and low } \\
\text { quality of life (QOL). } \\
\text { Work stress was } \\
\text { found to be a factor } \\
\text { for increased anxiety, } \\
\text { depression, and low } \\
\text { QOL. }\end{array}$ \\
\hline $\begin{array}{l}\text { Sil A et al., } \\
2020^{21}\end{array}$ & $\begin{array}{l}\text { Cross-sectional } \\
\text { study } \mathrm{n}=41\end{array}$ & $\begin{array}{l}\text { Patient Health } \\
\text { Questionnaire (PHQ- } \\
\text { 9) } \\
\text { Perceived Stress Scale } \\
\text { (PSS) }\end{array}$ & Dermatologists & Not mentioned & $26.82 \%$ & NA & $29.2 \%$ & $\begin{array}{l}\text { Long working time } \\
\text { and lack of proper } \\
\text { rest due to posting in } \\
\text { COVID-positive ward } \\
\text { shows a high } \\
\text { prevalence of stress } \\
\text { among HCW. those } \\
\text { who were away from } \\
\text { family also showed } \\
\text { similar result. }\end{array}$ \\
\hline $\begin{array}{l}\text { Saraswathi I } \\
\text { et al., } 2020^{22}\end{array}$ & $\begin{array}{l}\text { Prospective } \\
\text { longitudinal } \\
\text { study } n=217\end{array}$ & $\begin{array}{l}\text { Depression Anxiety } \\
\text { Stress Scale } 21 \text { Items } \\
\text { (DASS21) } \\
\text { Pittsburgh Sleep } \\
\text { Quality Index self- } \\
\text { administered } \\
\text { questionnaire }\end{array}$ & $\begin{array}{l}\text { Undergraduate } \\
\text { medical students }\end{array}$ & Not mentioned & $35.5 \%$ & $33.2 \%$ & $24.9 \%$ & $\begin{array}{l}\text { Because of the CoV- } \\
19 \text { outbreak and } \\
\text { quarantine, stress and } \\
\text { anxiety levels shown } \\
\text { to be increased in } \\
\text { HCW, and depression } \\
\text { symptoms remained } \\
\text { unaltered }\end{array}$ \\
\hline $\begin{array}{c}\text { Das A et al., } \\
2020^{23}\end{array}$ & $\begin{array}{l}\text { A cross- } \\
\text { sectional, } \\
\text { observational } \\
\text { study } \mathrm{n}=422\end{array}$ & $\begin{array}{l}\text { Patient Health } \\
\text { Questionnaire (PHQ- } \\
\text { 9) } \\
\text { Perceived Stress Scale } \\
\text { (PSS) }\end{array}$ & Doctors & $\begin{array}{l}\text { North: New Delhi; } \\
\text { West: Nagpur, } \\
\text { Maharashtra; and South: } \\
\text { Thiruvananthapuram, }\end{array}$ & $63.5 \%$ & NA & $45 \%$ & $\begin{array}{l}\text { Long working hours } \\
\text { and staying away } \\
\text { from families } \\
\text { reported to have a } \\
\text { significant role in } \\
\text { (continued on next page) }\end{array}$ \\
\hline
\end{tabular}


Table 1 (continued)

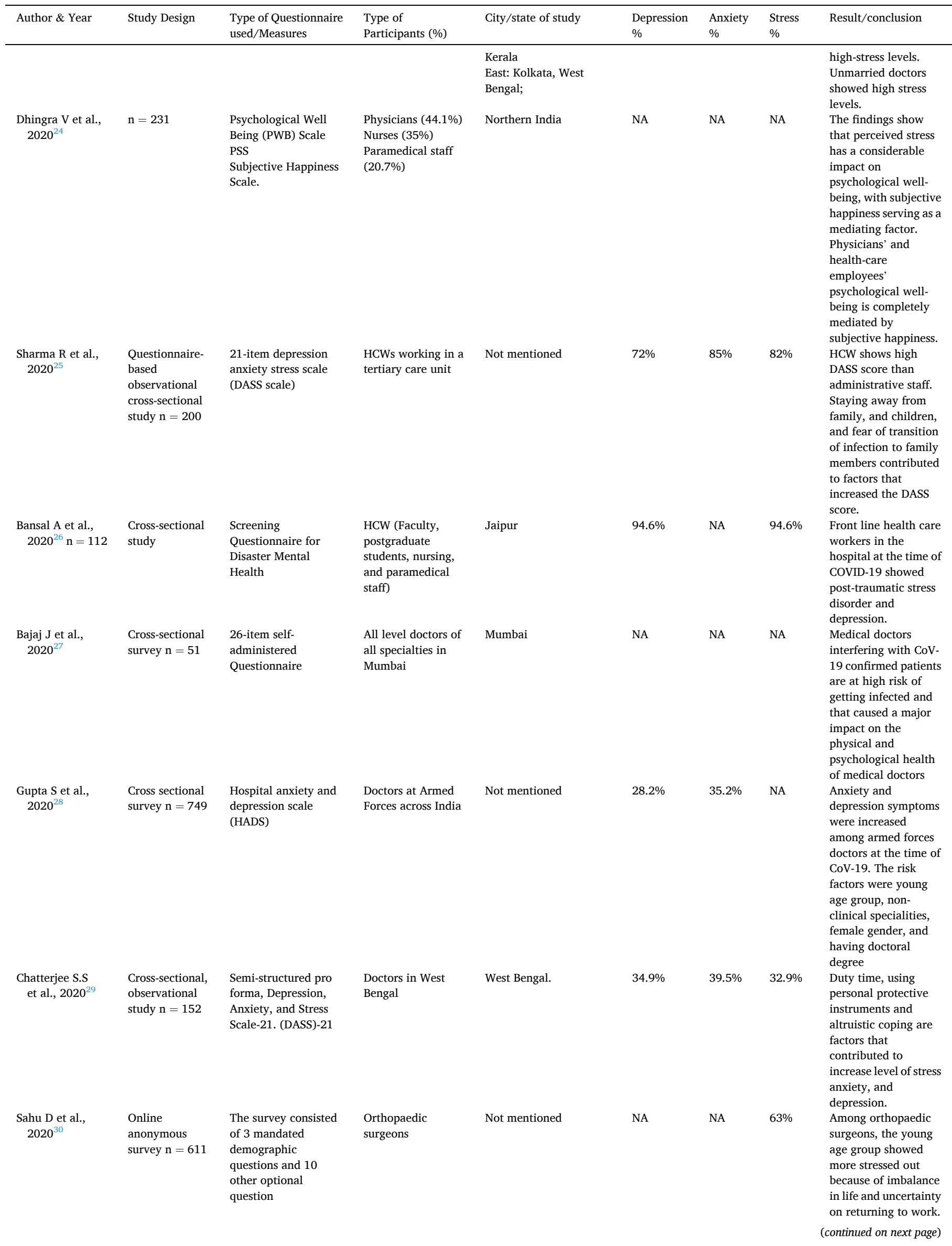


Table 1 (continued)

\begin{tabular}{|c|c|c|c|c|c|c|c|c|}
\hline Author \& Year & Study Design & $\begin{array}{l}\text { Type of Questionnaire } \\
\text { used/Measures }\end{array}$ & $\begin{array}{l}\text { Type of } \\
\text { Participants (\%) }\end{array}$ & City/state of study & $\begin{array}{l}\text { Depression } \\
\%\end{array}$ & $\begin{array}{l}\text { Anxiety } \\
\%\end{array}$ & $\begin{array}{l}\text { Stress } \\
\%\end{array}$ & Result/conclusion \\
\hline $\begin{array}{l}\text { Nair A.K.R et al., } \\
2020^{31}\end{array}$ & $\begin{array}{l}\text { Online survey } \\
\mathrm{n}=586\end{array}$ & $\begin{array}{l}\text { COVID-19 Peri- } \\
\text { traumatic Distress } \\
\text { Index and Perceived } \\
\text { stress scale }\end{array}$ & Indian endodontists & Not mentioned & NA & NA & $80 \%$ & $\begin{array}{l}\text { In the time of COVID- } \\
19 \text { related lockdown } \\
1 \text {-in- } 2 \text { endodontists } \\
\text { had distressed and } 4 \text { - } \\
\text { in- } 5 \text { had perceived } \\
\text { stress. Among them, } \\
\text { female endodontists } \\
\text { had more perceived } \\
\text { stress than males. }\end{array}$ \\
\hline $\begin{array}{l}\text { Grover R et al., } \\
2020^{32}\end{array}$ & $\begin{array}{l}\text { Cross-sectional } \\
\text { survey }\end{array}$ & $\begin{array}{l}\text { DASS }-21 \\
\text { questionnaire } \mathrm{n}=144\end{array}$ & $\begin{array}{l}\text { Ophthalmologists } \\
\text { in India }\end{array}$ & Not mentioned & $53 \%$ & $52 \%$ & $14 \%$ & $\begin{array}{l}\text { All of the } \\
\text { ophthalmologists } \\
(64.2 \%) \text { suffered } \\
\text { from mental health } \\
\text { problems. Among } \\
\text { them, } 52.7 \text { had } \\
\text { depression and } \\
\text { anxiety and } 14 \% \text { had } \\
\text { stress. Above } 40 \text { years } \\
\text { old with more than } 10 \\
\text { of experience showed } \\
\text { high stress. }\end{array}$ \\
\hline $\begin{array}{l}\text { Nathiya D et al., } \\
2021^{33}\end{array}$ & $\begin{array}{l}\text { Descriptive } \\
\text { quantitative } \\
\text { cross-sectional, } \\
\text { web-based } \\
\text { study } n=418\end{array}$ & $\begin{array}{l}\text { Impact of event scale- } \\
\text { revised } \\
\text { Connor-Davidson } \\
\text { resilience scale } \\
\text { The professional } \\
\text { quality of life } \\
\text { Feelings of health care } \\
\text { worker during } \\
\text { COVID-19 outbreak } \\
\text { was assessed by the } \\
\text { adapted } \\
\text { questionnaire by Cai } \\
\text { H et al. in a Chinese } \\
\text { study }\end{array}$ & $\begin{array}{l}\text { Healthcare workers } \\
\text { from different } \\
\text { departments of } \\
\text { hospital }\end{array}$ & Not mentioned & NA & NA & NA & $\begin{array}{l}\text { Female nurses and } \\
\text { doctors employed in } \\
\text { the emergency } \\
\text { division were } \\
\text { reported to have high } \\
\text { risk of psychological } \\
\text { distress. }\end{array}$ \\
\hline $\begin{array}{l}\text { Khanna RC et al., } \\
2020^{34}\end{array}$ & Online survey & PHQ-9 n = 2355 & Ophthalmologists & $\begin{array}{l}\text { Karnataka, Kerala, } \\
\text { Maharashtra, Tamil } \\
\text { Nadu, Telangana, Uttar } \\
\text { Pradesh, West Bengal, } \\
\text { Andhra Pradesh, Delhi, } \\
\text { Gujarat. }\end{array}$ & $32.6 \%$ & NA & NA & $\begin{array}{l}\text { Ophthalmologists of } \\
\text { younger age, female } \\
\text { and those who not } \\
\text { practice shows } \\
\text { significantly high } \\
\text { depression. }\end{array}$ \\
\hline $\begin{array}{l}\text { Nanjundaswamy } \\
\text { MH et al., } \\
2020^{35}\end{array}$ & Survey $\mathrm{n}=106$ & $\begin{array}{l}\text { Questionnaire on } \\
\text { stress and anxiety } \\
\text { during CoV-19 } \\
\text { pandemic }\end{array}$ & $\begin{array}{l}\text { Junior and senior } \\
\text { psychiatry resident } \\
\text { doctors }\end{array}$ & South India & NA & $35 \%$ & NA & $\begin{array}{l}\text { Among psychiatry } \\
\text { trainees, } 29 \% \\
\text { reported afraid to go } \\
\text { home and } 13 \% \text { feared } \\
\text { of stigma, } 35 \% \text { had } \\
\text { anxiety, loneliness, } \\
\text { and sadness }\end{array}$ \\
\hline $\begin{array}{l}\text { Podder I et al., } \\
2020^{36}\end{array}$ & $\begin{array}{l}\text { Web-based } \\
\text { cross-sectional } \\
\text { study } n=384\end{array}$ & $\begin{array}{l}\text { Stress assessment } \\
\text { (Perceived Stress } \\
\text { Scale (PSS-10) }\end{array}$ & $\begin{array}{l}\text { Dermatologists } \\
(37.5 \%) \text { and other } \\
\text { physicians }(62.5 \%)\end{array}$ & Across Eastern India & NA & NA & $85.9 \%$ & $\begin{array}{l}\text { Perceived stress was } \\
\text { higher in non- } \\
\text { dermatologists than } \\
\text { dermatologists. Also, } \\
\text { high perceived stress } \\
\text { was seen in females } \\
\text { and unmarried } \\
\text { doctors. Fear of } \\
\text { getting the infection, } \\
\text { fear of transferring } \\
\text { the infection to family } \\
\text { and co-workers, and } \\
\text { lack of protective } \\
\text { instruments were the } \\
\text { cause of increased } \\
\text { stress }\end{array}$ \\
\hline $\begin{array}{l}\text { Mishra S et al., } \\
2020^{37}\end{array}$ & $\begin{array}{l}\text { Cross-sectional } \\
\text { online } \\
\text { questionnaire- } \\
\text { based survey n } \\
=1253\end{array}$ & PSS & Dentists & Chhattisgarh & NA & NA & $79.24 \%$ & $\begin{array}{l}\text { Among dental } \\
\text { professionals the PSS } \\
\text { score were increased } \\
\text { during CoV-19 } \\
\text { pandemic. The main } \\
\text { risk factor identified } \\
\text { was they can't touch } \\
\text { their family members } \\
\text { because of the } \\
\text { prolonged working } \\
\text { hours } \\
\text { (continued on next page) }\end{array}$ \\
\hline
\end{tabular}


Table 1 (continued)

\begin{tabular}{|c|c|c|c|c|c|c|c|c|}
\hline Author \& Year & Study Design & $\begin{array}{l}\text { Type of Questionnaire } \\
\text { used/Measures }\end{array}$ & $\begin{array}{l}\text { Type of } \\
\text { Participants (\%) }\end{array}$ & City/state of study & $\begin{array}{l}\text { Depression } \\
\%\end{array}$ & $\begin{array}{l}\text { Anxiety } \\
\%\end{array}$ & $\begin{array}{l}\text { Stress } \\
\%\end{array}$ & Result/conclusion \\
\hline $\begin{array}{l}\text { Pandey U et al., } \\
2020^{38}\end{array}$ & $\begin{array}{l}\text { Cross-sectional } \\
\text { survey } \mathrm{n}=83\end{array}$ & $\begin{array}{l}\text { Depression-PHQ-9 } \\
\text { Anxiety GAD-7 scale }\end{array}$ & $\begin{array}{l}\text { Medical students } \\
\text { and junior doctors } \\
\text { of the Obstetrics } \\
\text { and Gynaecology } \\
\text { department }\end{array}$ & Varanasi & $7.3 \%$ & $9.8 \%$ & NA & $\begin{array}{l}\text { Female gender } \\
\text { reported high anxiety } \\
\text { and depression than } \\
\text { male. Direct contact } \\
\text { with Cov-19 patient } \\
\text { not affected doctors } \\
\text { psychologically }\end{array}$ \\
\hline $\begin{array}{l}\text { Gupta S et al., } \\
2020^{39}\end{array}$ & $\begin{array}{l}\text { Prospective } \\
\text { study } n=1124\end{array}$ & $\begin{array}{l}\text { Questions about the } \\
\text { COVID-19 pandemic } \\
\text { Hospital Anxiety and } \\
\text { Depression Scale }\end{array}$ & $\begin{array}{l}\text { Doctors }(0.8 \%) \\
\text { Nurses }(18.4 \%) \\
\text { Paramedics }(12 \%) \\
\text { Administrators } \\
(2.04 \%) \\
\text { Supporting staff } \\
\text { members }(0.88 \%)\end{array}$ & Not mentioned & $31.4 \%$ & $37.2 \%$ & NA & $\begin{array}{l}\text { Prevalence of anxiety } \\
\text { and depression was } \\
\text { reported as } 37.2 \% \\
\text { and } 31.4 \% \\
\text { respectively. } \\
\text { Following were } \\
\text { reported as risk } \\
\text { factors of anxiety } \\
\text { female, age group } \\
\text { between } 20 \text { and } 35 \\
\text { years, unmarried. } \\
\text { Risk factors of } \\
\text { depression were age } \\
\text { group and } \\
\text { employment at } \\
\text { primary care hospital. }\end{array}$ \\
\hline
\end{tabular}

\section{Methods}

Initially, all synonyms, search terms and entry terms resembling to the population (healthcare workers), condition (COVID-19), outcome (psychological stress, anxiety, depression other mental health data, were collected from various sources such as Pub Med (Medical subject heading $[\mathrm{MeSH}] \mathrm{Terms})$, ClinicalTrials.gov and the previous systematic reviews. The following electronic databases were searched, MEDLINE (PubMed), the Cochrane Library, Scopus, and Web of Science. Article language were limited to English. Bibliography of all the included studies and a random search in Google, Google Scholar and Research Gate were performed to find any other relevant studies.

\subsection{Inclusion and exclusion criteria}

Studies which are published in English which is of full text and conducted in India were included. Studies published in non-English language and that were conducted outside India was excluded.

\subsection{Study selection}

Every article was screened by reading title and abstract to find if the article meets the criteria for inclusion. All duplicates were removed and Screening of articles was performed to find out whether articles pass the inclusion criteria under the types of studies, participants, interventions, settings, and outcomes. First and second authors separately screened title of all studies, if the title did not mention about country, population and intervention then abstract screening was done if the abstract did not mention then full text screening was done on the time of first pass only, as it is anyway required to read the full article for the screening. If an article was excluded, the reason was noted, the third author screened all the selected studies. Total of 23 studies were included for quality evaluation.

\subsection{Quality evaluation}

Risk of bias/methodological quality was checked differently by first and second authors and reviewed by a third author using the following tools: Downs and Black checklist for observational studies was used to assess the methodological quality. It contains 27 questions which has to be graded as "Yes", "No" and "Unable to determine" as per the available information. Previously, studies have used a modified version by simplification of the power question and awarding only 1 point if a study had adequate power to recognize a clinically significant effect, where the probability value for difference being due to chance is $<5 \%$, if a study did not mention statistical power, it was deemed either "no" or "unable to determine" and given a score of 0 . There are 5 sections which includes the study quality (10 items), external validity (3 items), study bias (7 items), confounding and selection bias ( 6 items), and power ( 1 item). Each question if answered "yes" gets a score of 1, except for the 5 th question which can get a score of 2 if answered "yes". ${ }^{15}$

\subsection{Data extraction}

Data retrieval was performed on a pilot-tested standardized form on Microsoft Excel by first author and reviewed by second and a third author. We extracted data according to authors, year of publication, country of study, pandemic, design and method, participants, mental health issues, context, to extract information about the interventions used to address stress, anxiety and mental health), and key result. A narrative summary and tables (Table no-1) were used to summarize the characteristics and results of included studies.

\subsection{Statistical analysis}

RevMan 5.3 was used for 5 meta-analyses. The number of events and total number of participants were used for prevalence outcome and results were presented in terms of prevalence rate with $95 \%$ confidence interval (CI), whereas mean with standard deviation (SD) were used for continuous outcomes and results were presented as mean along with $95 \%$ CI. We used the fixed effect model in case of non-significant heterogeneity (I $<50 ; \mathrm{P}>0.1$ ), whereas a random effect model was employed in this study in case of substantial heterogeneity (I2>50\%; P $<0.10)^{16}$ We could not perform subgroup analysis due to insufficient data, though it was planned. Sensitivity analysis was not performed as the effect size was in percentage along with $95 \%$ confidence interval.

Funnel plot was used for the visual inspection of publication bias. It is a form of scatter plot with a single point for each study, in which X-axis denoting the prevalence rate and the $\mathrm{Y}$-axis representing the study precision, commonly standard error.

\section{Result}

After eliminating 135 duplicates from 818 studies, the remaining 


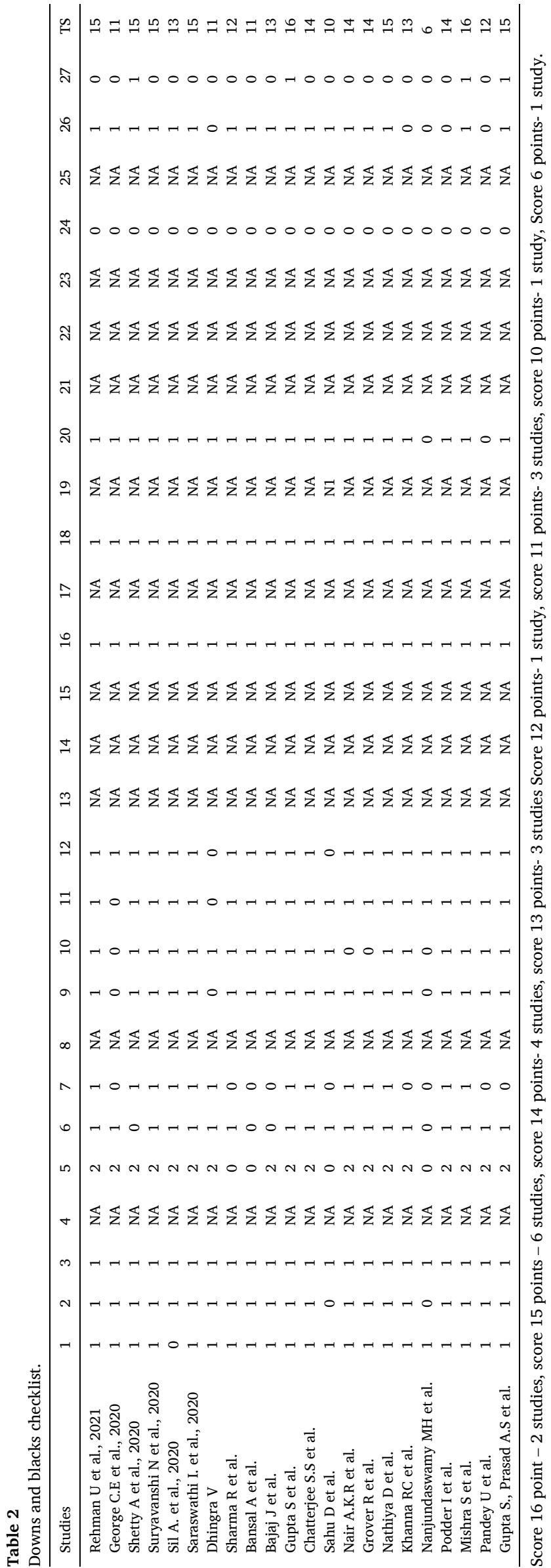

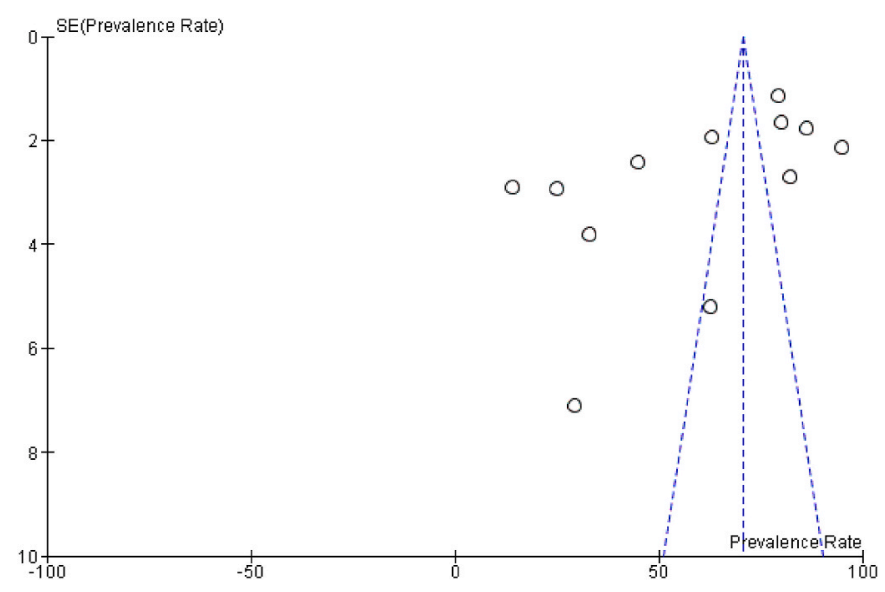

Fig. 2. Funnel plot for publication bias.

638 studies were screened for the title, abstract, and full text out of which 654 were omitted due to irrelevant content. 26 articles with full text were screened and 3 omitted as it was not fulfilling the criteria. This review included 23 full-text articles, as shown in detail in the PRISMA (Preferred Reporting Items for Systematic Reviews and Meta-Analyses) flow-chart in Fig. 1. Details and characteristics of these articles are also provided in Table 1.

\subsection{Risk of bias in included studies}

The Risk of bias assessment was performed using Downs and Black checklist. Downs and Black checklist were used to assess the quality of original or primary source research article. A total of five sections of questions are included. 1.Reporting 2. External validity 3. Internal validity-bias 4. Internal validity - confounding 5. Power. Out of 27 questions, 16 Questions were only eligible for our study as few questions were not relevant for the studies included in our review; hence the total score was 17 . Out of that $2(8 \%)$ studies scored 16 point, $6(26 \%)$ studies scored 15 points, $4(17.3 \%)$ studies scored 14 points, $3(13 \%)$ studies scored 13 points, 1 (4.3\%) study scored 12 point, $3(13 \%)$ studies scored 11 points, 1 (4.3\%) study scored 10 points, and 1 (4.3\%) study scored 6 points (Table 2).

\subsection{Investigating heterogeneity and publication bias}

To investigate the heterogeneity of the studies, the $\mathrm{I}^{2}(\%)$ indices for the prevalence of stress $\left(\mathrm{I}^{2}: 99 \%\right)$, anxiety $\left(\mathrm{I}^{2}: 98 \%\right)$, depression $\left(\mathrm{I}^{2}: 99\right.$. $\%)$, Worry $\left(\mathrm{I}^{2}: 93 \%\right)$, Sleeping problem $\left(\mathrm{I}^{2}: 81 \%\right)$ and Fear $\left(\mathrm{I}^{2}: 94 \%\right)$ were obtained. Due to the high heterogeneity in the studies, the random effects model was used in the analysis of findings. Visual inspection of the funnel plots revealed an obvious asymmetry, which indicates that there is a chance of publication bias in the included studies (Fig. 2).

\subsection{Meta-analysis}

Prevalence of depression among 5796 participants in 5 studies was 41.90\% (95\% Confidence Interval [CI]: 29.17 to 54.64)(Fig. 3), Prevalence of anxiety in 10 studies with sample size of 3059 was $42.87 \%$ (95\% Confidence Interval [CI]: 30.26 to 55.49)(Fig. 4), Prevalence of stress in 12 studies with 4209 participants recorded a prevalence rate of 58.04 (95\% CI: 44.81-71.28)(Fig. 5), Prevalence of worry in 3 studies with 276 participants demonstrated a prevalence rate of 66.54 (95\% CI: 46.54-86.53)(Fig. 6), Prevalence of sleeping problem in 3 studies with 416 participants recorded a prevalence rate of 31.94 (95\% CI: 21.38-42.49)(Fig. 7), Prevalence of fear in 3 studies with 244 participants recorded a prevalence rate of 59.47 (95\% CI: 36.52-82.41)(Fig. 8). 5 studies with 1926 participants reported that the overall mean score for 


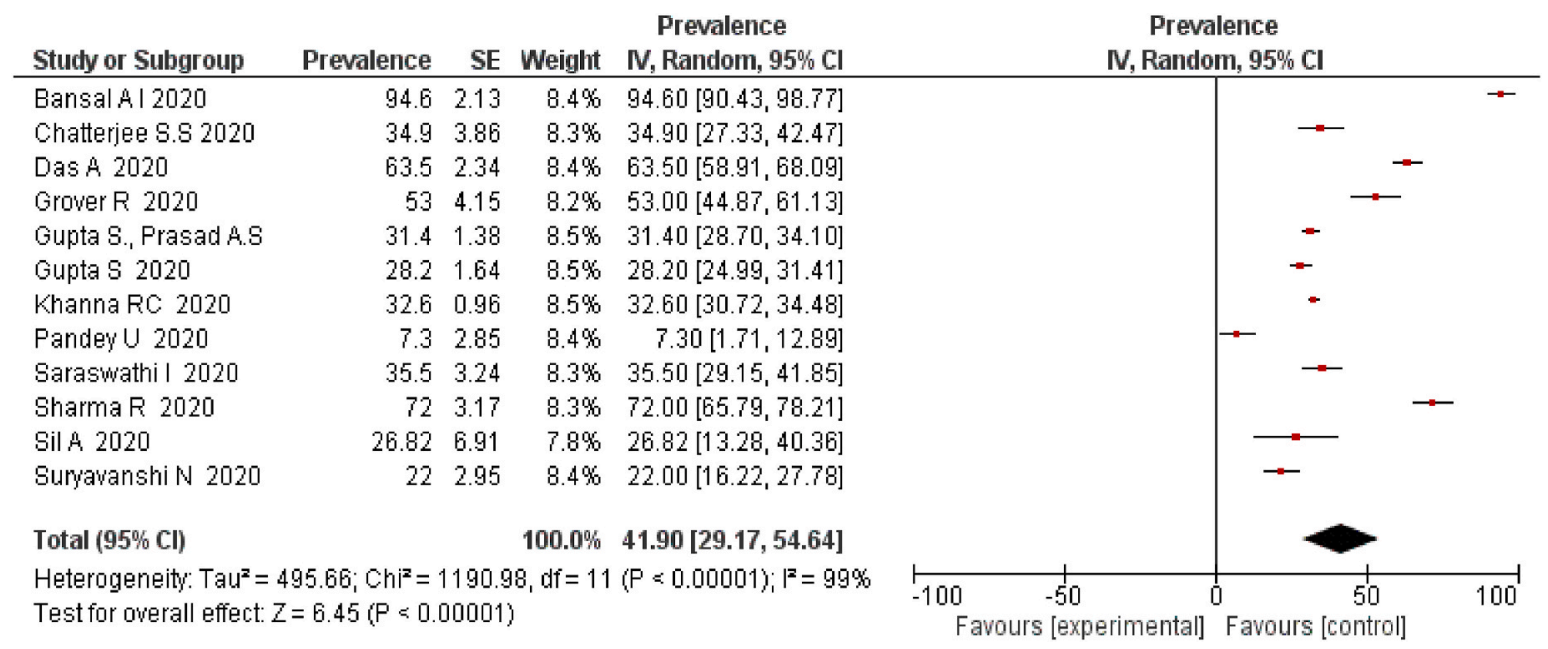

Fig. 3. Prevalence rate of depression among HCW during COVID-19.

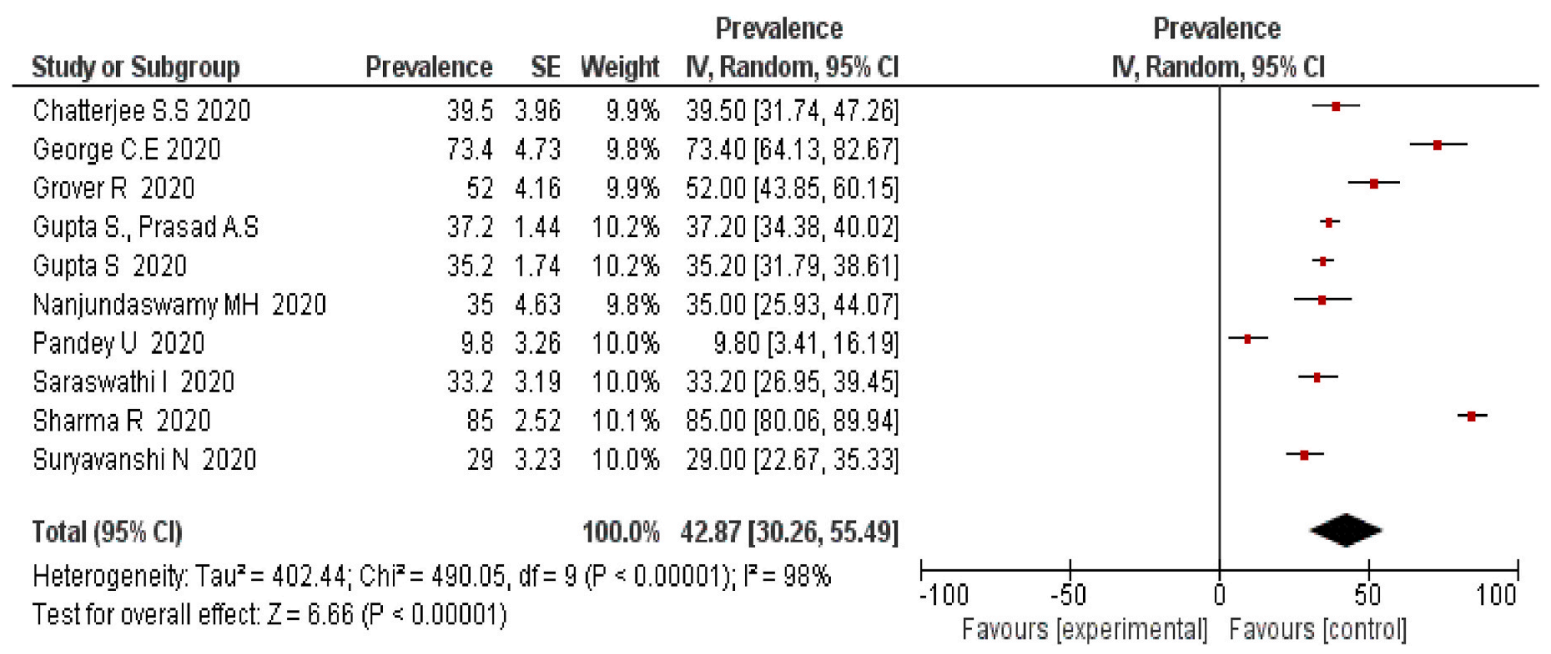

Fig. 4. Prevalence rate of anxiety among HCW during COVID-19.

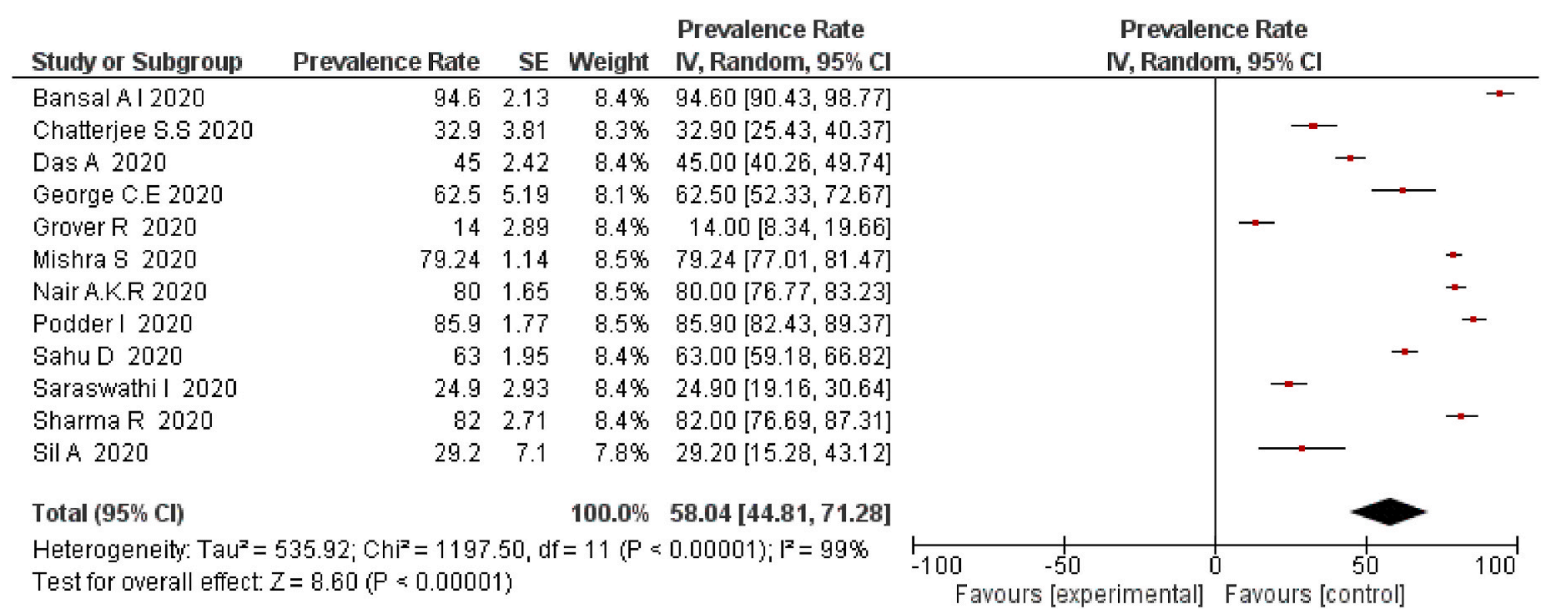

Fig. 5. Prevalence rate of stress among HCW during COVID-19.

anxiety was found to be 7.66 (95\% CI: 5.71-9.61) (Fig. 9), 8 studies with 3086 participants reported that the overall mean score for stress was found to be 17.33 (95\% CI: 10.42-24.24) (Fig. 10), 5 studies with 1562 participants reported that the overall mean score for depression was found to be 7.48 (95\% Confidence Interval: 4.69-10.28) (Fig. 11). 


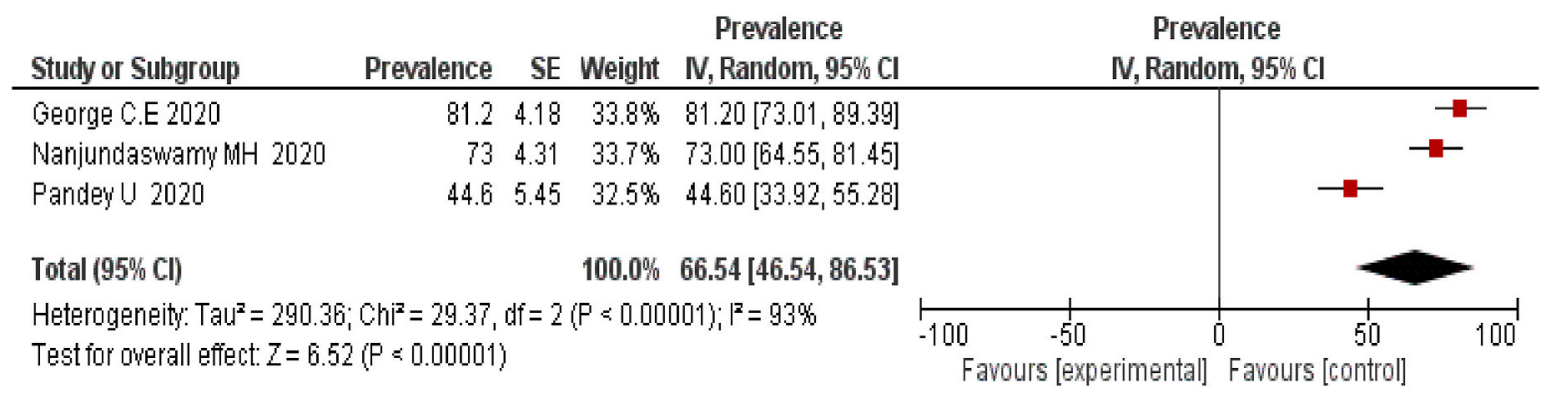

Fig. 6. Prevalence rate of worry among HCW during COVID-19.

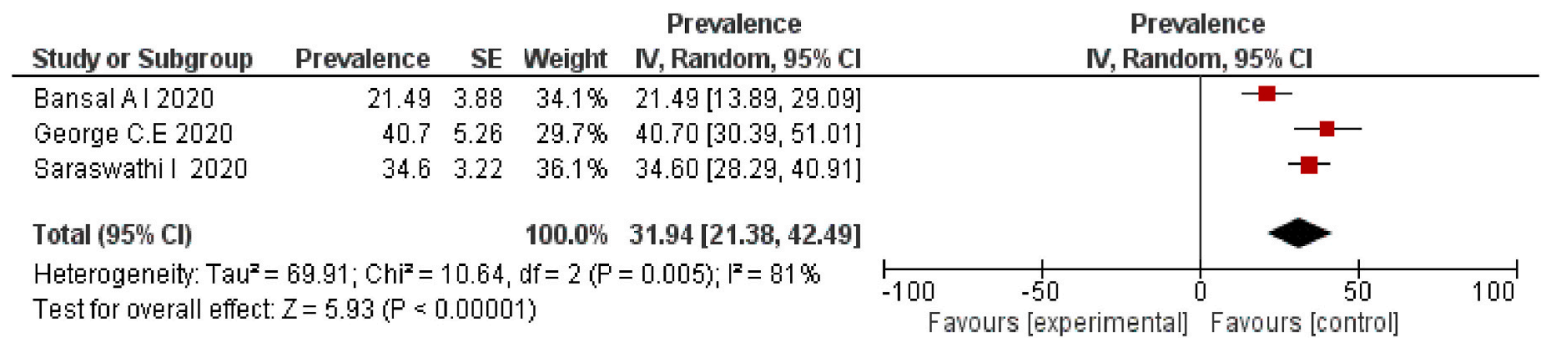

Fig. 7. Prevalence rate of sleeping problems among HCW during COVID-19.

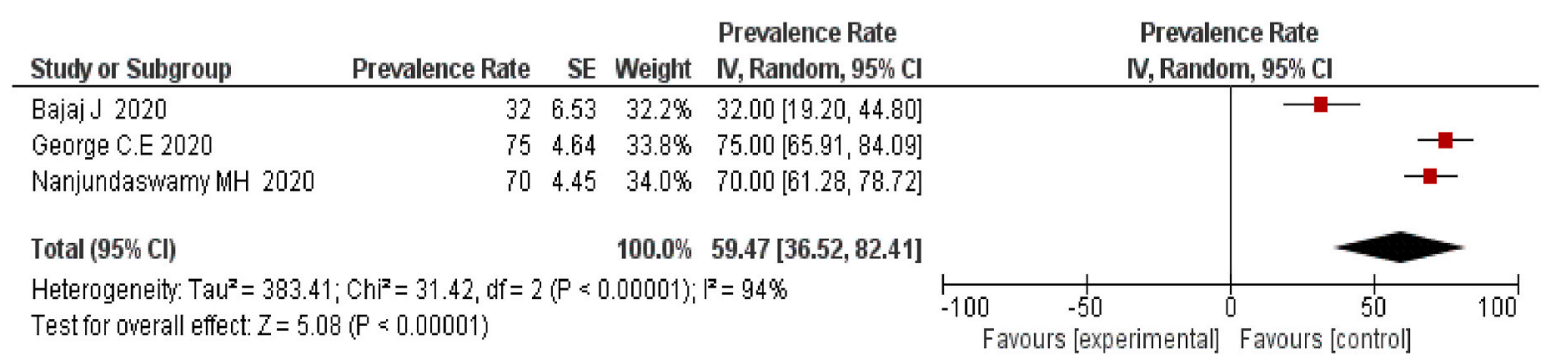

Fig. 8. Prevalence rate of fear among HCW during COVID-19.

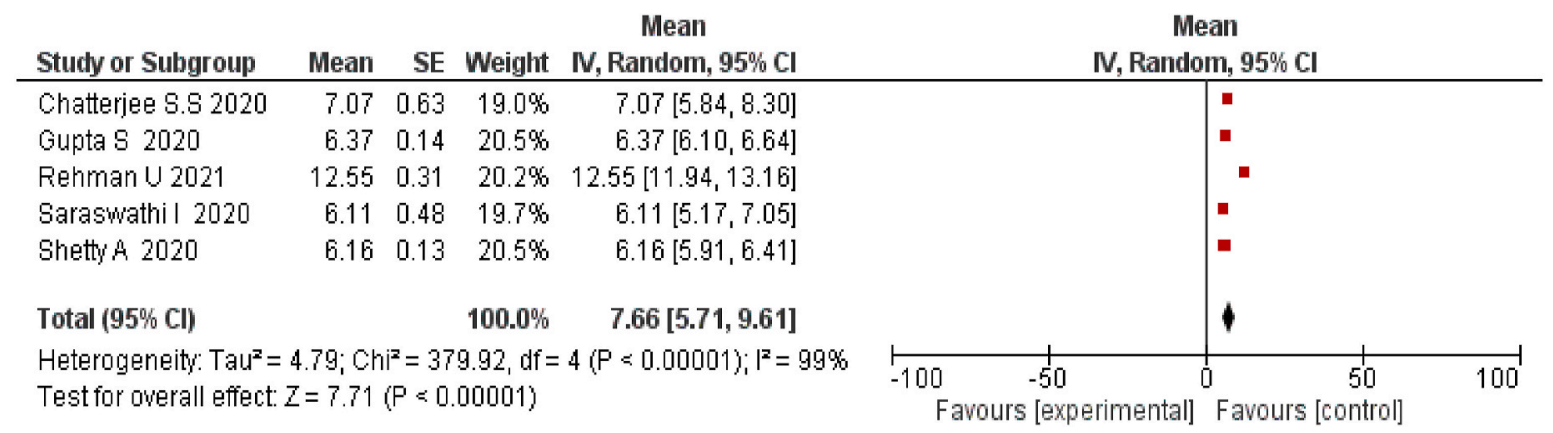

Fig. 9. The level of anxiety among HCW during COVID-19.

\section{Discussion}

COVID-19 pandemic has become a serious problem of mental anguish in healthcare workers (HCW). HCW are suffering from stress, depression, anxiety, insomnia due to the Cov-19 pandemic. ${ }^{40,41}$ Gender, age, place of work, profession, department of work are associated with the increased anxiety, stress and insomnia in Health Care Workers at the time of COVID-19 is an independent risk factor for getting stress among HCW. ${ }^{40}$ Extended working hours, emergency calls, a quarantine, and separation from friends due to professional commitments puts HCW under extreme stress, anxiety, and frustration. They are more worried for their thoughts as like, they might transfer infection to their loved ones and others. ${ }^{42}$ After checking the article by standardise and random search we understand, this is the first review which reviewing of depression and anxiety associated with COVID-19 pandemic among healthcare professionals in India.

When compared to exiting systematic review and meta-analysis, 13 studies with 33,062 participants found $23.2 \%$ pooled anxiety in 12 studies, and $22.8 \%$ pooled depression in 10 studies. ${ }^{43}$ In our study pooled prevalence of anxiety was $42.87 \%$ in 10 studies and pooled prevalence of depression was $41.9 \%$ in 12 studies.

A study done by Gonzalo Salazar de Pablo et al. ${ }^{44}$ found HCW has gone through on $43.7 \%$ fear, $37.9 \%$ insomnia, $34.4 \%$ burnout, $37.8 \%$ psychological distress, $29.0 \%$ anxiety, $26.3 \%$ depressive symptoms. In 


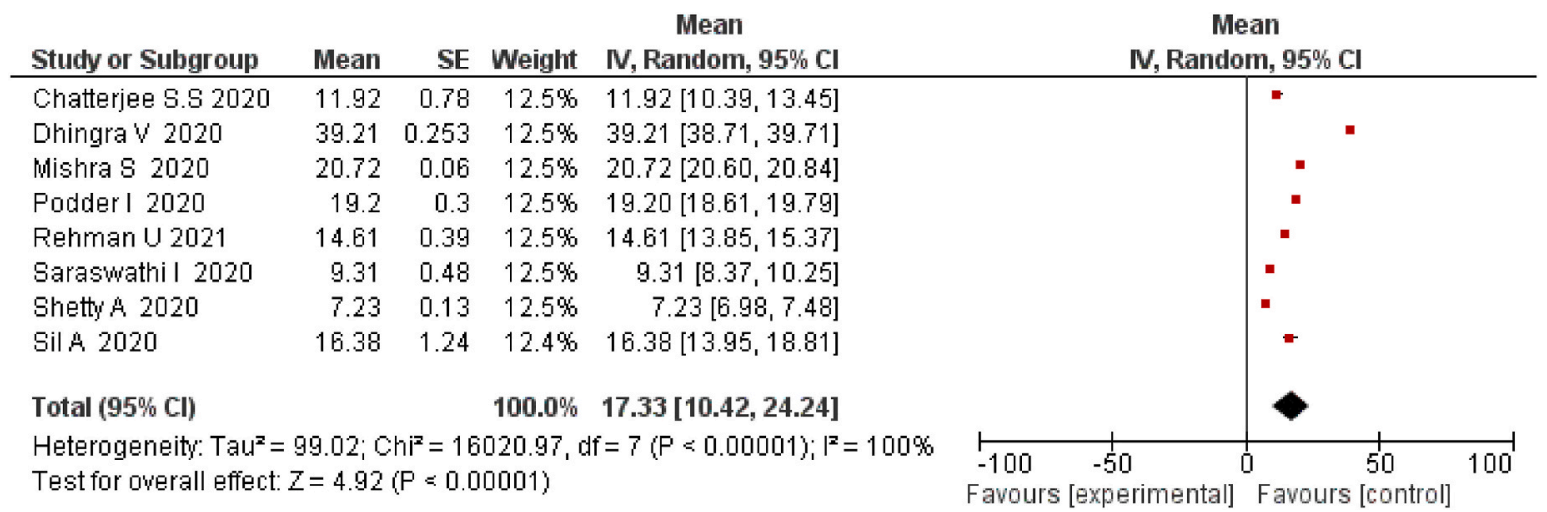

Fig. 10. The level of stress among HCW during COVID-19.

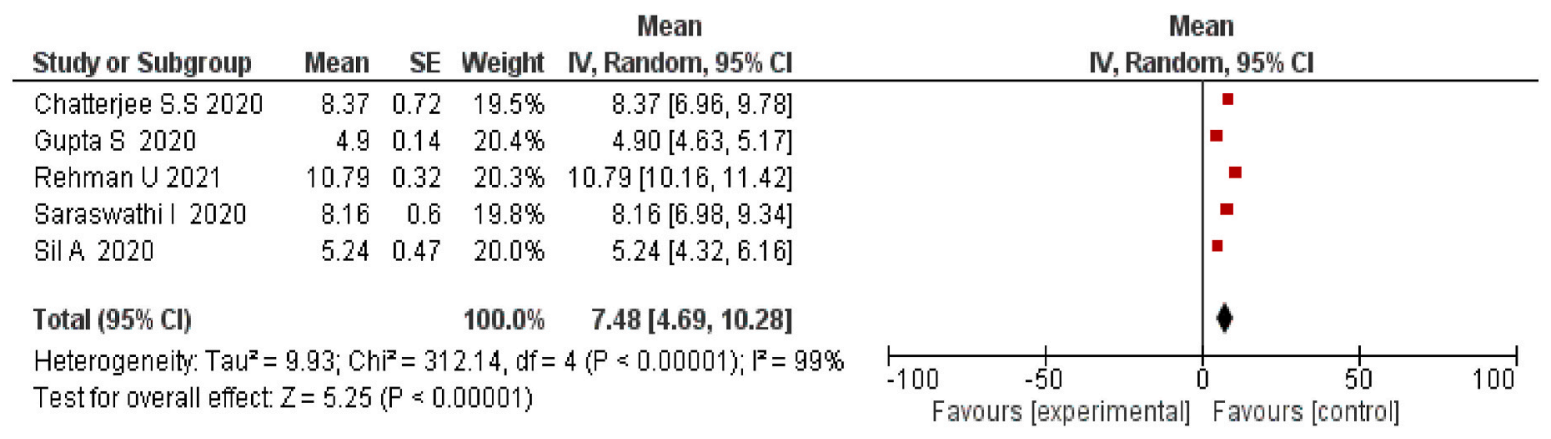

Fig. 11. The level of depression among HCW during COVID-19.

our study we could find HCW has gone through 66.54\% worry, 31.94\% sleep problems, $59.47 \%$ fear.

In this review, we could find that the health care workers are going through serious mental health care problems. There are so many confounding factors found in health care sectors and within HCWs, that include HCWs have a high chance of getting the infection so also spreading infection, HCW have cared about their family and friend, so they are worried about spreading the infection to them. ${ }^{18,25,36}$

COVID-19 pandemic stuck the normal flow of health care sectors, because of the sudden outbreak had lack of protective instruments, HCW worked over time and they are forced to work in COVID-19 ward these factors influenced HCW to tend to fall on depression and anxiety. ${ }^{17,21,23,29}$

HCW working with COVID-19 patients despite they have worn protective instruments they should go to quarantine. Which puts them through mental health problems like depression anxiety, and stress. ${ }^{22}$ COVID-19 outbreak affected more on females, young and unmarried HCW. These factors show direct relation on high depression and stress level. ${ }^{33,28,34,31,30,19,23,38 \text {,and } 39}$

The inherent heterogeneity across research is a fundamental disadvantage that should be considered. This is the first comprehensive study and meta-analysis of the pooled prevalence of depression and anxiety among HCW in India during the COVID-19 outbreak that we are aware of. Despite the fact that multiple research used the same tests, different assessment scales and cut-offs were used for population screening. Another drawback is that while numerous studies were conducted in the same region/country, they may have included the same population.

\section{Conclusion}

The mental health problems among HCW during the COVID-19 were ranged from $30 \%$ to $60 \%$. There should be a better plan to mitigate the impact of COVID-19 on HCW and appropriate counselling should be provided to overcome the mental health issues among HCW. More interventions need to be implemented which can tackle the mental health problem among HCW. The government should give psychological assistance, cut working hours, and hire more people, as well as provide free medical care if necessary. All of these resources can help health-care employees deal with mental health issues. The findings of this study can be used to quantify staff support needs and to inform tiered and personalised treatments that improve resilience and reduce susceptibility in pandemic situations.

\section{Funding}

This research did not receive any specific grant from funding agencies in the public, commercial, or not-for-profit sectors.

\section{Declaration of competing interest}

The authors report no conflicts of interest.

\section{Acknowledgement}

Authors would like to thank Mr. Muhammed Rasheed, Research Scholar, Manipal College of Pharmaceutical Sciences, Manipal Academy of Higher Education for the support and help provided.

\section{References}

1 Mahalmani VM, Mahendru D, Semwal A, et al. COVID-19 pandemic: a review based on current evidence. Indian journal of pharmacology. 2020 Mar;52(2):117.

2 Zhou P, Yang XL, Wang XG, et al. A pneumonia outbreak associated with a new coronavirus of probable bat origin. nature. 2020 Mar;579(7798):270-273.

3 Cucinotta D, Vanelli M. WHO declares COVID-19 a pandemic. Acta Bio Medica: Atenei Parmensis. 2020;91(1):157.

4 Jee Y. WHO international health regulations emergency committee for the COVID-19 outbreak. Epidemiology and health. 2020:42.

5 Kakar A, Nundy S. COVID-19 in India. Journal of the Royal Society of Medicine. 2020 Jun;113(6):232-233. 
6 Martin AL, Natalia ES, Ana MA. The SARS-CoV-2 coronavirus and the COVID-19 outbreak. International braz $\mathrm{j}$ urol: official journal of the Brazilian Society of Urology.;46.

7 Evanoff BA, Strickland JR, Dale AM, et al. Work-Related and personal factors associated with mental well-being during the COVID-19 response: survey of health care and other workers. Journal of medical Internet research. 2020;22(8), e21366.

8 Bohlken J, Schömig F, Lemke MR, Pumberger M, Riedel-Heller SG. COVID-19 pandemic: stress experience of healthcare workers-a short current review. Psychiatrische Praxis. 2020 Apr 27;47(4):190-197.

9 Rossi R, Socci V, Pacitti F, et al. Mental health outcomes among frontline and second line health care workers during the coronavirus disease 2019 (COVID-19) pandemic in Italy. JAMA network open. 2020 May 1;3(5), e2010185.

10 WHO 20216 September. https://covid19.who.int/; 2021.

11 WHO 20216 September. https://covid19.who.int/region/searo/country/in; 2021.

12 Fegert JM, Vitiello B, Plener PL, Clemens V. Challenges and burden of the Coronavirus 2019 (COVID-19) pandemic for child and adolescent mental health: a narrative review to highlight clinical and research needs in the acute phase and the long return to normality. Child and adolescent psychiatry and mental health. $2020 \mathrm{Dec}$ $14,1-1$.

13 OECD 202131 March 2020 OECD policy responses to coronavirus (COVID-19) COVID-19: protecting people and societies. https://www.oecd.org/coronavirus/poli cy-responses/covid-19-protecting-people-and-societies-e5c9de1a/\#biblio-d1e2308.

14 Lai J, Ma S, Wang Y, et al. Factors associated with mental health outcomes among health care workers exposed to coronavirus disease 2019. JAMA network open. 2020 Mar 2;3(3), e203976.

15 Downs SH, Black N. The feasibility of creating a checklist for the assessment of the methodological quality both of randomised and non-randomised studies of health care interventions. Journal of Epidemiology \& Community Health. 1998 Jun 1;52(6): 377-384.

16 Review Manager (RevMan). [Computer Program]. Version 5.3. Copenhagen: The Nordic Cochrane Centre, The Cochrane Collaboration; 2014.

17 Rehman U, Shahnawaz MG, Khan NH, et al. Depression, anxiety and stress among Indians in times of Covid-19 lockdown. Community mental health journal. $2021 \mathrm{Jan} ; 57$ (1):42-48.

18 George CE, Inbaraj LR, Rajukutty S, de Witte LP. Challenges, experience and coping of health professionals in delivering healthcare in an urban slum in India during the first 40 days of COVID-19 crisis: a mixed method study. BMJ open. 2020 Nov 1;10 (11), e042171.

19 Shetty A, Bhat R, Shetty P, Hegde MN, Nayak UK, D'souza N. The psychological impact of the COVID-19 pandemic on dental healthcare professionals. Journal of International Oral Health. 2020 Nov 1;12(8):98.

20 Suryavanshi N, Kadam A, Dhumal G, et al. Mental health and quality of life among healthcare professionals during the COVID-19 pandemic in India. Brain and behavior. 2020 Nov;10(11), e01837.

21 Sil A, Das A, Jaiswal S, et al. Mental health assessment of frontline COVID-19 dermatologists: a Pan-Indian multicentric cross-sectional study. Dermatologic Therapy. 2020 Jun 22.

22 Saraswathi I, Saikarthik J, Kumar KS, Srinivasan KM, Ardhanaari M, Gunapriya R. Impact of COVID-19 outbreak on the mental health status of undergraduate medical students in a COVID-19 treating medical college: a prospective longitudinal study. PeerJ. 2020 Oct 16;8, e10164.

23 Das A, Sil A, Jaiswal S, et al. A study to evaluate depression and perceived stress among frontline Indian doctors combating the COVID-19 pandemic. The primary care companion for CNS disorders. 2020 Oct 8;22(5).

24 Dhingra V, Dhingra M. Effect of perceived stress on psychological well-being of health care workers during COVID 19: mediating role of subjective happiness. European Journal of Molecular \& Clinical Medicine.;7(02):2020.

25 Sharma R, Saxena A, Magoon R, Jain MK. A cross-sectional analysis of prevalence and factors related to depression, anxiety, and stress in health care workers amidst the COVID-19 pandemic. Indian Journal of Anaesthesia. 2020 Sep;64(Suppl 4):S242.

26 Bansal A, Jain S, Sharma L, Kumar M, Sharma A. A cross-sectional study to assess the psychosocial impact of COVID-19 pandemic on health-care workers at a tertiary care hospital in India. International Journal of Academic Medicine. 2020 Jul 1;6(3):197.
27 Bajaj JS, Solanki SL. Study of risk factors and psychological impact in physicians diagnosed with COVID-19: an online, postexposure, cross-sectional survey. Journal of Anaesthesiology Clinical Pharmacology. 2020 Jul 1;36(3):345.

28 Gupta S, Kohli K, Padmakumari P, et al. Psychological health among armed forces doctors during COVID-19 pandemic in India. Indian Journal of Psychological Medicine. 2020 Jul; 42(4):374-378.

29 Chatterjee SS, Bhattacharyya R, Bhattacharyya S, Gupta S, Das S, Banerjee BB. Attitude, practice, behavior, and mental health impact of COVID-19 on doctors. Indian Journal of Psychiatry. 2020 May;62(3):257.

30 Sahu D, Agrawal T, Rathod V, Bagaria V. Impact of COVID 19 lockdown on orthopaedic surgeons in India: a survey. Journal of clinical orthopaedics and trauma. 2020 May 1;11:S283-S290.

31 Ramachandran Nair AK, Savrimalai Karumaran C, Kattula D, Thavarajah R, Arunachalam Mohandoss A. Stress levels of Indian endodontists during COVID-19 pandemic. Rev. cuba. estomatol. 2020:e3445.

32 Grover R, Dua P, Juneja S, Chauhan L, Agarwal P, Khurana A. "Depression, anxiety and stress" in a cohort of registered practicing ophthalmic surgeons, post lockdown during COVID-19 pandemic in India. Ophthalmic Epidemiology. 2020 Nov 14:1-8.

33 Nathiya D, Suman S, Singh P, Raj P, Tomar BS. WITHDRAWN: Mental Health Outcome and Professional Quality of Life Among Healthcare Worker during COVID19 Pandemic: A (FRONTLINE-COVID) Survey. InAnnales Médico-Psychologiques, Revue Psychiatrique 2021 Jan 6. Elsevier Masson.

34 Khanna RC, Honavar SG, Metla AL, Bhattacharya A, Maulik PK. Psychological impact of COVID-19 on ophthalmologists-in-training and practising ophthalmologists in India. Indian journal of ophthalmology. 2020 Jun;68(6):994.

35 Nanjundaswamy MH, Pathak H, Chaturvedi SK. Perceived stress and anxiety during COVID-19 among psychiatry trainees. Asian journal of psychiatry. 2020 Dec;54: 102282.

36 Podder I, Agarwal K, Datta S. Comparative analysis of perceived stress in dermatologists and other physicians during national lock-down and COVID-19 pandemic with exploration of possible risk factors: a web-based cross-sectional study from Eastern India. Dermatologic Therapy. 2020 Jul;33(4), e13788.

37 Mishra S, Singh S, Tiwari V, Vanza B, Khare N, Bharadwaj P. Assessment of level of perceived stress and sources of stress among dental professionals before and during the COVID-19 outbreak. Journal of International Society of Preventive \& Community Dentistry. 2020 Nov;10(6):794.

38 Pandey U, Corbett G, Mohan S, et al. Anxiety, depression and behavioural changes in junior doctors and medical students associated with the coronavirus pandemic: a cross-sectional survey. The Journal of Obstetrics and Gynecology of India. 2021 Feb;71 (1):33-37.

39 Gupta S, Prasad AS, Dixit PK, Padmakumari P, Gupta S, Abhisheka K. Survey of prevalence of anxiety and depressive symptoms among 1124 healthcare worker during the coronavirus disease 2019 pandemic across India. Medical Journal Armed Forces India. 2020 Sep 1.

40 Spoorthy MS, Pratapa SK, Mahant S. Mental health problems faced by healthcare workers due to the COVID-19 pandemic-A review. Asian journal of psychiatry. 2020; 51:102119. https://doi.org/10.1016/j.ajp.2020.102119.

41 Collins R. COVID-19: nurses have responded, now it is time to support them as we move forward. Healthcare management forum. 2020;33(5):190-194. https://doi.org/ $10.1177 / 0840470420953297$.

42 Khanagar SB, Al-Ehaideb A, Vishwanathaiah S, Maganur PC, Varadarajan S, Patil S. Depression, anxiety, and psychological distress among health-care providers during the outbreak of the life-threatening coronavirus disease (COVID-19). J Contemp Dent Pract. 2020;21:471-472.

43 Pappa S, Ntella V, Giannakas T, Giannakoulis VG, Papoutsi E, Katsaounou P. Prevalence of Depression, Anxiety, and Insomnia Among Healthcare Workers during the COVID-19 Pandemic: A Systematic Review and Meta-Analysis. Brain, Behavior, and Immunity. 2020 May 8.

44 de Pablo GS, Serrano JV, Catalan A, et al. Impact of coronavirus syndromes on physical and mental health of health care workers: systematic review and metaanalysis. Journal of affective disorders. 2020 Jun 25. 